\title{
Phorbol myristate acetate induces cellular senescence in rat microglia in vitro
}

\author{
DAN CAO ${ }^{1,2}$, XIAO-HONG LI ${ }^{2}$, XIAO-GUANG LUO ${ }^{2}$, HONG-MEI YU ${ }^{2}$, LI-SHU WAN $^{3}$, LING WEI $^{1}$ and YAN REN ${ }^{2}$ \\ ${ }^{1}$ Department of Geriatrics, The Fourth People's Hospital of Shenyang, Shenyang, Liaoning 110031; \\ ${ }^{2}$ Department of Neurology, The First Affiliated Hospital of China Medical University, Shenyang, Liaoning 110001; \\ ${ }^{3}$ Department of Neurology, The First Hospital of Dandong, Dandong, Liaoning 118000, P.R. China
}

Received September 30, 2019; Accepted March 19, 2020

DOI: $10.3892 /$ ijmm.2020.4587

\begin{abstract}
The present study aimed to establish a cellular model to test the hypothesis that oncogene-induced senescence (OIS) is triggered by aging-related activation of microglia. Primary microglia were incubated with phorbol 12-myristate 13-acetate (PMA), and $\beta$-galactosidase $(\beta$-Gal) staining was applied to subsequent assessment of cellular senescence. Moreover, flow cytometry was employed for examinations of cell cycle arrest and senescence-associated proteins, p53 and p21 were measured by western blotting. Furthermore, examination of tumor necrosis factor $\alpha(\mathrm{TNF}-\alpha)$ and interleukin-1 $\beta$ (IL-1 $\beta$ ) were carried out with microglia supernatants undergoing age-related degenerative diseases in the nervous system, using ELISA. PC12 cells were co-cultured with microglia activated by aging-related alteration(s) to evaluate whether apoptosis was increased in PC12 cells. Cellular senescence-associated $\beta-\mathrm{Gal}$ staining showed that microglial $\beta$-Gal expression gradually increased with prolonged PMA stimulation. Microglia in the group receiving $72 \mathrm{~h}$ of PMA stimulation displayed the highest percentage of cells arrested in G0/G1, the highest amount of senescence-associated expression of p53 and p21, and the most prominent secretion of TNF- $\alpha$ and IL-1 $\beta$. In comparison with controls, an increase of apoptotic PC12 cells was detected, which were co-cultured with aging microglia. Taken together, microglia tend to undergo senescence after PMA treatment,
\end{abstract}

Correspondence to: Dr Yan Ren, Department of Neurology, The First Affiliated Hospital of China Medical University, 155 North Nanjing Street, Heping, Shenyang, Liaoning 110001, P.R. China

E-mail: renyan0411@sina.com; dancao0901@163.com

Abbreviations: OIS, oncogene-induced senescence; PMA, phorbol 12-myristate 13-acetate; $\beta$-Gal, $\beta$-galactosidase; TNF- $\alpha$, tumor necrosis factor- $\alpha$; IL-1 $\beta$, interleukin-1 $\beta$; PD, Parkinson's disease; DA, dopaminergic; PFA, paraformaldehyde; DCF, dichlorodihydrofluorescein; ROS, reactive oxygen species; CNS, central nervous system

Key words: phorbol myristate acetate, oncogene-induced senescence, microglia suggesting that microglial senescence is associated with inactivation of certain oncogenes.

\section{Introduction}

Microglia are considered to be the largest population of residual immune cells, which play a major role in maintaining brain homeostasis. Microglia not only protect neurons by phagocytosing pathogens and harmful particles in the tissue, but also, they exhibit toxic effects upon neurons by secreting proinflammatory cytokines (1). Age-associated microglial activation contributes to increasing sensitivity of dopaminergic neurons to neurotoxins (2). Microglia play essential roles in the numerous types of neuropathogenesis, including Alzheimer's disease and Parkinson's disease (PD) among other aging-related neurodegenerative diseases (3-5). Previous studies (6-8) have demonstrated that microglia activated by lipopolysaccharide, reduces dopaminergic (DA) neuron death caused by 1-methyl-4-phenyl-1,2,3,6-tetrahydropyridine, also known as a neurotoxin in newborn rats. However, DA neuron death increases in aged rats under the same conditions, suggesting a functional switch of microglia from neuroprotection to neurotoxicity. Microglial senescence may potentially explain this functional switch. Thus, microglial senescence is likely to be responsible for pathological progression and is considered as a pivotal step involved in age-associated neurodegenerative diseases (9).

A variety of internal and external stimuli, such as oxidative stress (10), injury (11), radiation (12), tumor protein activation (13), and chemical mutagens (14) can induce cellular senescence. Cellular senescence is basically defined as termination of, or a decrease in cell division and expression of senescence-related proteins, including elevated endogenous $\beta$-galactosidase activity (15) and p21 (16). The most common pathological senescence is called oncogene-induced senescence (OIS). The initiation of OIS is an endogenous protective mechanism in the body, by which tumor growth and progression are restrained. Threatened by malignant transformation, cells cease their abnormal proliferation and initiate the senescence progression, due to activation oncogenes mutations or inactivation of tumor suppressor genes $(13,17,18)$. Phorbol 12-myristate 13-acetate (PMA), capable of effectively activating protein kinase $\mathrm{C}$ as well as being a potential carcinogen, 
has a significant role in promoting cellular differentiation, mitogenesis, survival, apoptosis and transformation (19) through the activation of oncogenes $(20,21)$.

Therefore, the present study hypothesized that: i) Senescent microglia accumulate and release inflammatory cytokines, which drastically alter the cerebral microenvironment; and ii) microglial senescence can be over-activated by other pathological stimuli and cause damage to DA neurons. A previous study on adult rats found that microglial senescence can be induced by repeatedly intra-nigrostriatal injection of PMA (20). In this study, in vitro experiments were performed with microglial cultures to assess the effects of malignant transformation on the occurrence of microglia senescence and to explore the potential mechanism(s) underlying OIS signaling. The current study provides a basis to explore the possible mechanisms of PD pathogenesis further and to develop interventions through the regulation of dynamic cellmicroenvironmental interactions.

\section{Materials and methods}

Microglia and PC12 Culture. Primary microglia were obtained from Wuhan Pricells Biotechnology and Medicine Co., Ltd. All the procedures regarding animal experiments were carried out in compliance of the guidelines for the Care and Use of Laboratory Animals, which were approved and supervised by the Ethics Committee of China Medical University. As with previous studies, microglia cultures were isolated from brain tissues of Sprague-Dawley rat pups (Wuhan Pricells Biotechnology and Medicine Co., Ltd.) (22-24). In brief, after sacrificing the rats, the whole brains were dissected out in pre-cold minimum essential medium supplemented with L-glutamine (MEM; Invitrogen; Thermo Fisher Scientific, Inc.). The meninges were peeled off, followed by rinsing the remaining tissue. Afterwards, the tissues were in turn strained, digested with dispase (1.5 U/ml; Gibco; Thermo Fisher Scientific, Inc.), and pelleted by centrifugation at $300 \mathrm{x} \mathrm{g}$ for $10 \mathrm{~min}$ at room temperature. Following re-suspension in MEM, cells were seeded in medium containing MEM combined with $10 \%$ heat-inactivated fetal bovine serum (FBS; Sigma-Aldrich; Merck $\mathrm{KGaA}$ ) and $0.05 \mathrm{mg} / \mathrm{ml}$ of gentamycin (Invitrogen; Thermo Fisher Scientific, Inc.) in an incubator with $5 \% \mathrm{CO}_{2}$ at $37^{\circ} \mathrm{C}$ for $48 \mathrm{~h}$. Afterwards, the medium was refreshed to remove cellular debris as well as non-adherent cells. In order to harvest microglia after 5-6 days culture, the flasks were shaken for 3-4 h on an orbital shaker at $70 \times \mathrm{g}\left(37^{\circ} \mathrm{C}, 5 \%\right.$ $\mathrm{CO}_{2}$ ), followed by collecting the supernatant that contained microglia and centrifugation at $300 \mathrm{x} \mathrm{g}$ for $10 \mathrm{~min}$ at room temperature. The pellet was re-suspended in freshly prepared medium containing MEM, 2\% heat-inactivated FBS (GE Healthcare; Hyclone ${ }^{\mathrm{TM}}$; cat. no. SH30088.03), $0.002 \mathrm{mg} / \mathrm{ml}$ of penicillin and $0.002 \mathrm{mg} / \mathrm{ml}$ of streptomycin. After seeding, it normally took 2-3 days for microglia to settle at $37^{\circ} \mathrm{C}$ in an incubator containing $5 \% \mathrm{CO}_{2}$. PC12 cell lines obtained from Chinese Academy of Science, were employed as a substitute for neurons. They were cultured at $37^{\circ} \mathrm{C}$ in a humidified incubator containing 5\% $\mathrm{CO}_{2}$, utilizing RPMI 1640 medium (Thermo Fisher Scientific, Inc.; Gibco ${ }^{\mathrm{TM}}$; cat. no. A1049101) supplemented with 5\% FBS and $10 \%$ horse serum (Thermo
Fisher Scientific, Inc.; Gibco ${ }^{\mathrm{TM}}$; cat. no. 026050088). All the in vitro experiments were performed in compliance with guidelines approved and supervised by the Ethics Committee of China Medical University.

Cell proliferation test (MTT). Microglia were seeded onto a 96-well plate at the density of $1 \times 10^{4}$ cell per well and cultured in MEM media with $0.4 \% \mathrm{FBS}$ for $24 \mathrm{~h}$ prior to the addition of PMA at various concentrations and different time periods (24, 48, 72, and $96 \mathrm{~h})$. Cells of different groups were stained with MTT $(0.5 \mathrm{mg} / \mathrm{ml})$ for $4 \mathrm{~h}$ at $37^{\circ} \mathrm{C}$. The optical density at $570 \mathrm{~nm}$ was determined, and counted with a Countstar Automated Cell Counter, which uses trypan blue staining for less than three minutes at room temperature to exclude live and dead cells. The proliferation rate $(\mathrm{X})$ was determined using the following formula: $\mathrm{X}=$ cell counts of treatment group/ cell counts of control group.

Experimental procedure and groups. Either PMA stimulation (100 $\mathrm{ng} / \mathrm{ml}$ in saline, which was diluted from stock solution in DMSO) or saline were added to the microglia culture for 24,48 or $72 \mathrm{~h}$, respectively. They were subdivided into four groups as follows: i) Microglia stimulated with normal saline for 24, 48 and $72 \mathrm{~h}$ as controls; ii) microglia stimulated by $24-\mathrm{h}$ PMA administration; iii) microglia stimulated by 48-h PMA administration, and iv) microglia stimulated by 72-h PMA administration.

Microglia-PC12 co-culture. Microglia were seeded onto permeable transwell chamber (BD Falcon; Becton, Dickinson and Company) at the density of $1 \times 10^{4}$ cell per well while PC12 cells onto 24 -well culture plates at $5 \times 10^{4}$ cell per well. They were both allowed to adhere for $48 \mathrm{~h}$. Cell media had been refreshed $24 \mathrm{~h}$ prior to treatment. Microglia were treated with PMA stimulation (100 ng/ml) with 72-h administration. Subsequently, activated microglia underwent aging-related alteration(s). The transwell chamber with over-activated microglia can be easily transferred into the 24-well plate that had already been cultured with PC12 cells for co-culture for $24 \mathrm{~h}$, thereby allowing material and/or energy exchange between PC12 cells and microglia activated by aging-related alteration(s). Finally, the transwell chamber and microglia were simultaneously removed from the system of the co-culture experiment, and the remaining PC12 cells were then tested alone on the 24-well plate under x400 magnification using a light microscope.

Cell cycle test (flow cytometry). When reaching 70-80\% confluence, cells were treated with $0.25 \%$ trypsin (Hyclone; GE Healthcare) after rinses, followed by fixation with ice-cold $70 \%$ cold ethanol overnight. Samples were then re-suspended in $0.5 \mathrm{ml}$ of PBS and then underwent treatment with RNase (Sigma-Aldrich; Merck KGaA) to remove RNA. Afterwards, they were ready for staining with propidium iodide (SigmaAldrich; Merck KGaA) for $1 \mathrm{~h}$ at $4^{\circ} \mathrm{C}$ in the darkness. Using a Becton Dickinson FACScan system, their DNA was assessed by fluorescence-activated cell sorting. For analysis, first the pulse width-pulse area map was used to set the gate, a single cell population was selected, then this gating was applied to the scatter plot and significant cell debris was excluded. CellFIT 
software (a Windows-based 2D version of CellFIT, known as Zazu was downloaded from webpage of Dr. Shane Hutson in Vanderbilt University, https://my.vanderbilt.edu/shanehutson/ software/cellfit-cellular-force-inference-toolkit/) was used to calculate the percentage of cells in each phase. The G0/G1phase cell ratio was calculated as $\mathrm{G}_{0} / \mathrm{G}_{1} /\left(\mathrm{G}_{0} / \mathrm{G}_{1}+\mathrm{S}+\mathrm{G}_{2} / \mathrm{M}\right)$. The $\mathrm{S}$-phase cell ratio was calculated as $\mathrm{S} /\left(\mathrm{G}_{0} / \mathrm{G}_{1}+\mathrm{S}+\mathrm{G}_{2} / \mathrm{M}\right)$.

Senescence-associated $\beta$-galactosidase (SA- $\beta$-Gal) staining. After PBS rinses, microglia were fixed with $4 \%$ paraformaldehyde (PFA) for $15 \mathrm{~min}$ at room temperature, followed by removal of the remaining PFA solution. The incubated cells were kept in darkness overnight at $37^{\circ} \mathrm{C}$ in a sealed and wet container. Those cells were covered by fresh staining buffer containing $1 \mathrm{mg} / \mathrm{ml}$ of X-gal, $40 \mathrm{mM}$ of citric acid/sodium phosphate ( $\mathrm{Ph} \mathrm{6.0),} 5 \mathrm{mM}$ of potassium ferricyanide, $150 \mathrm{mM}$ of $\mathrm{NaCl}$ and $2 \mathrm{mM}$ of $\mathrm{MgCl}_{2}$, which was substituted with normal saline immediately before capturing using a light microscope under x400 magnification. Total and SA- $\beta-$ Gal positive cells were counted, based on at least three distinct fields that were randomly selected, each of which contained 100 cells in total under each condition.

Immunofluorescence staining. After PBS rinses, microglia were fixed with 4\% PFA for $20 \mathrm{~min}$ at room temperature, followed by PBS rinses again and permeabilization with $0.2 \%$ Triton $\mathrm{X}-100$ for $10 \mathrm{~min}$. After blocking with $10 \%$ goat serum (Thermo Fisher Scientific, Inc.; Gibco ${ }^{\mathrm{TM}}$; cat. no. 16210064) in PBS at room temperature for $30 \mathrm{~min}$, cells were then incubated overnight at $4{ }^{\circ} \mathrm{C}$ with primary antibodies against p53 (1:400; Cell Signaling Technology, Inc., cat. no. 48818) and p21 (1:400; Abcam, cat. no. ab218311), and incubated at room temperature for $2 \mathrm{~h}$ with fluorescent secondary antibodies (Thermo Fisher Scientific, Inc.; Invitrogen $^{\mathrm{TM}}$; cat. no. A-11030 for goat anti-mouse IgG conjugated with Alexa Fluor 546, and A-11035 for goat anti-rabbit IgG conjugated with Alexa Fluor 546) in the darkness. Cells were then stained with DAPI for $3 \mathrm{~min}$ at room temperature. After rinses with PBS, the cells were analyzed under a microscope using an inverted mode or a confocal laser scanning mode (LX71; Olympus Corporation).

Western blot analysis. Radioimmune precipitation assay buffer containing $1 \%$ Nonidet P-40, $0.5 \%$ sodium deoxycholate, $0.1 \% \mathrm{SDS}, 100 \mathrm{mg} / \mathrm{ml}$ of phenylmethylsulfonyl fluoride, 50 kallikrein inactivating units $/ \mathrm{ml}$ aprotinin and $1 \mathrm{mM}$ of sodium orthovanadate in PBS, was freshly prepared. Using the bicinchoninic acid assay Protein Assay (Beyotime Institute of Biotechnology), the protein concentration of each sample was evaluated. Accordingly, $100 \mathrm{mg}$ of protein were loaded upon a $15 \%$ SDS-polyacrylamide gel and then they were transferred to polyvinylidene difluoride membranes (EMD Millipore). Immediately following blocking at room temperature for $60 \mathrm{~min}$ or $4^{\circ} \mathrm{C}$ overnight, using western blocking buffer (Beyotime Institute of Biotechnology; western blocking buffer; cat. no. P0023B-100 ml), the membrane was then incubated with primary antibodies against p53 (1:1,000; Cell Signaling Technology, Inc.; cat. no. 48818) and p21 (1:1,000; Abcam; cat. no. ab218311) in a 5\% skimmed milk-TBST solution containing $10 \mathrm{mM}$ of Tris- $\mathrm{Cl}(\mathrm{pH} 7.5), 150 \mathrm{mM}$ of $\mathrm{NaCl}$ and $0.05 \%$ Tween 20 at $4^{\circ} \mathrm{C}$ overnight. After rinses, all blots were then incubated by corresponding secondary antibody conjugated to horseradish peroxidase $(1: 2,500$; Santa Cruz Biotechnology, Inc; cat. no. sc-2357 for mouse anti-rabbit IgG conjugated with HRP, and sc-516102 for anti-mouse IgG Kappa binding protein secondaries) for $1 \mathrm{~h}$ at room temperature. Proteins were visualized via chemiluminescent methods (Beyotime Institute of Biotechnology, Chemiluminescent EMSA kit; cat. no. GS009) based on the manufacturer's protocol. Quantitative analyses for protein levels were carried out by gray value analysis in Gel-Pro-Analyzer (Media Cybernetics, Inc.; Gel-Pro Analyzer Version 6.3 image analysis software).

Measurement of intracellular ROS formation. After rinses and re-suspension in FBS-free RPMI, microglia were incubated with $10 \mu \mathrm{M}$ of dichlorodihydrofluorescein -diacetate (DCFH-DA; Beyotime Institute of Biotechnology) at $37^{\circ} \mathrm{C}$ for $20 \mathrm{~min}$, followed by rinsing again with $\mathrm{FBS}$-free RPMI. The fluorescence intensity of DCF was evaluated in a microplate-reader under $485 \mathrm{~nm}$ excitation wavelength and $535 \mathrm{~nm}$ emission wavelength. Regarding cell observation using an inverted fluorescence microscope under x 200 magnification, they were stained with $10 \mu \mathrm{M}$ of DCFH-DA for $20 \mathrm{~min}$ at $37^{\circ} \mathrm{C}$ after rinses with FBS-free RPMI and then they were captured using confocal microscopy under x 200 magnification.

Cytokine secretion test (ELISA). Microglia were stimulated with PMA at the indicated time $(0,24,48,72$ or $96 \mathrm{~h}$ following administration) and culture media removed. FBS-free RPMI was used for microglia culture for $24 \mathrm{~h}$ and then microglial supernatants were collected for ELISA assay. According to the standard protocols provided by manufacturers, ELISA kits were adopted to detect the TNF- $\alpha$ (Wuhan Boster Biological Technology, Ltd.; PicoKine ${ }^{\mathrm{TM}}$; cat. no. EK0525), IL-1 $\beta$ (Wuhan Boster Biological Technology, Ltd.; PicoKine ${ }^{\mathrm{TM}}$; cat. no. EK0392), serial dilutions of the protein standards and supernatant samples were added in a 96-well ELISA plate precoated with TNF- $\alpha$ and IL- $1 \beta$ antibody, respectively. Samples then underwent incubation with shaking at $4^{\circ} \mathrm{C}$ overnight. Subsequently following rinses in each well, the primary antibodies were applied for further incubation at $37^{\circ} \mathrm{C}$ for another $2 \mathrm{~h}$, followed by incubating with HRP-conjugated secondary antibody for $1 \mathrm{~h}$. Afterwards, 3,3'-diaminobenzidine solution was added at room temperature and the mixture was kept in the darkness for $\sim 15-30 \mathrm{~min}$. Afterwards, the reaction was terminated by stopping solution and the densities of mixture were measured at $450 \mathrm{~nm}$ absorbance. Triplicates were used for each sample.

Detection of apoptosis of PC12 (flow cytometry). Apoptotic and necrotic cells were quantified by Annexin V binding and PI uptake. An apoptosis kit (Neobioscience Technology Co., Ltd.; cat. no. FAK015.50) was adopted for apoptosis detection. Briefly, PC12 cells were centrifuged at $300 \mathrm{x}$ g for $5 \mathrm{~min}$ at $4^{\circ} \mathrm{C}$ and collected in a $1.5 \mathrm{ml}$ Eppendorf-tube and then washed twice with cold PBS for 2 times, after being resuspended in $195 \mu$ l binding buffer, $5 \mu 1$ FITC conjugated with Annexin V were applied to each sample and incubated for $3 \mathrm{~min}$ in the 
A

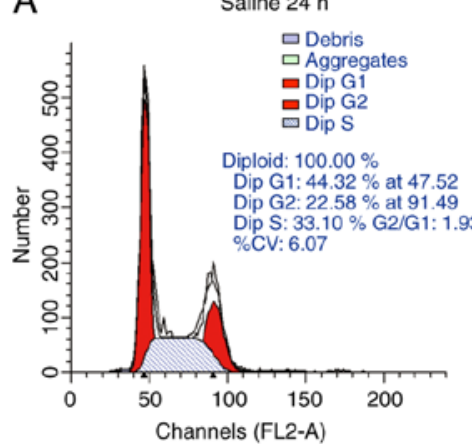

PMA $24 \mathrm{~h}$

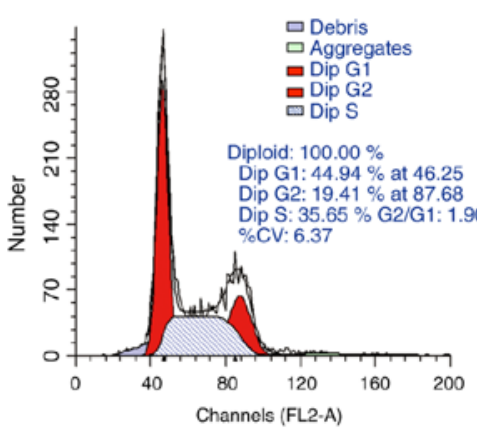

Saline $48 \mathrm{~h}$

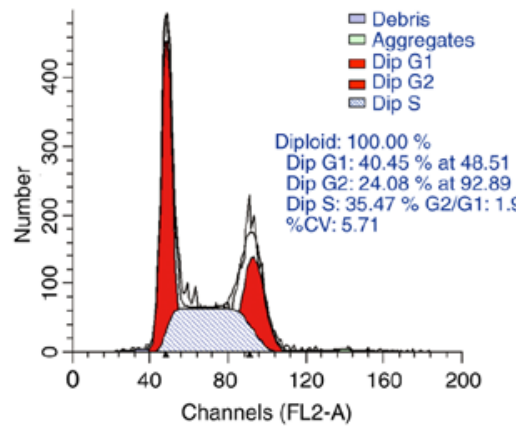

PMA $48 \mathrm{~h}$

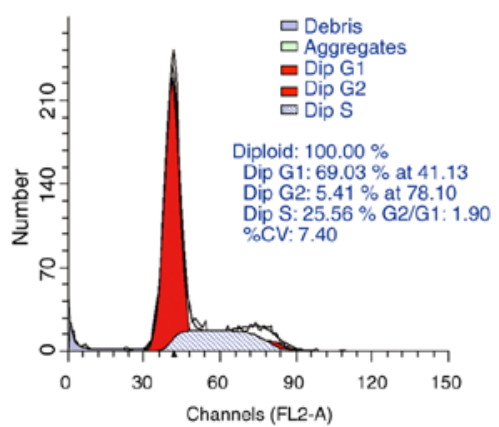

Saline $72 \mathrm{~h}$

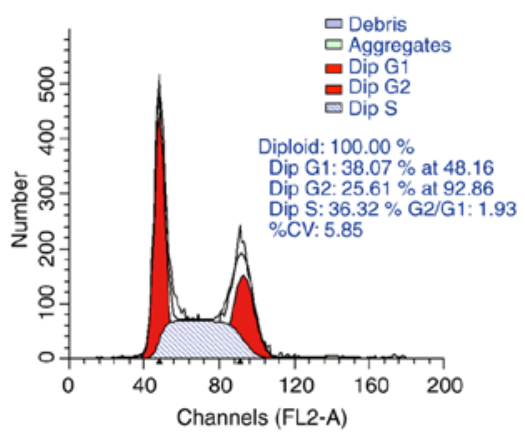

PMA $72 \mathrm{~h}$

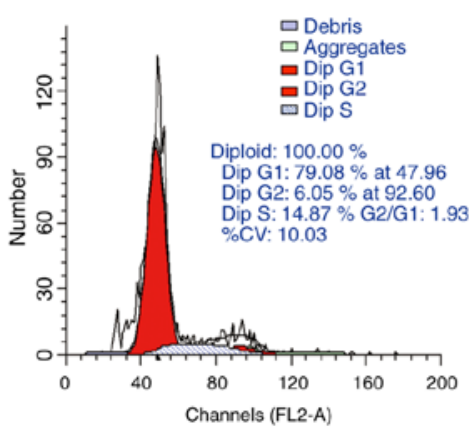

B
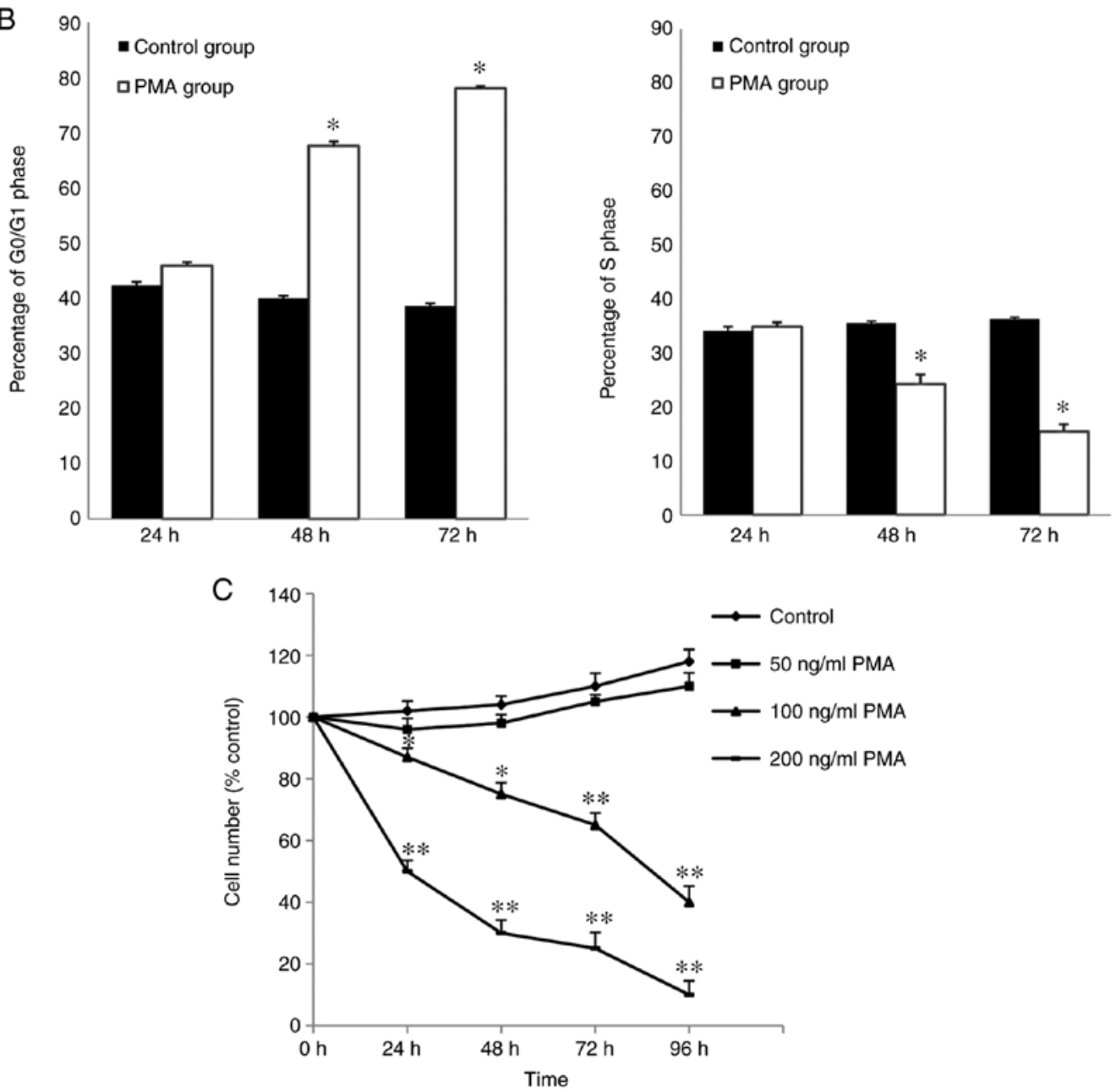

Figure 1. PMA induces cellular senescence of microglia and inhibits their proliferation. (A) The proliferative evaluation of cells treated with PMA at each time point indicated that they were significantly suppressed as compared with the saline-treated $24 \mathrm{~h}$ group. (B) Microglia receiving PMA stimulation for 24,48 and $72 \mathrm{~h}$ exhibited an increase in cell number, which have been arrested in the G0/G1 phase whereas lowered in the S phase, as compared to the saline-treated 24, 48 and 72 -h group, respectively $(\mathrm{n}=10)$. $\mathrm{P}<0.05$ vs. the saline-treated 24 -h group. (C) Different concentrations of PMA induced proliferation of microglia. Cells treated with PMA (100 and $200 \mathrm{ng} / \mathrm{ml}$ ) had a significantly inhibited cell number compared with corresponding control groups at 24, 48 and $72 \mathrm{~h}$, respectively, while $96 \mathrm{~h}$ group showed obviously enhanced cellular death. The signal intensity per cell was measured. ${ }^{*} \mathrm{P}<0.05$ and ${ }^{* *} \mathrm{P}<0.01$ vs. Control group.PMA, phorbol 12 -myristate 13 -acetate. 
A

$\mathrm{Oh}$

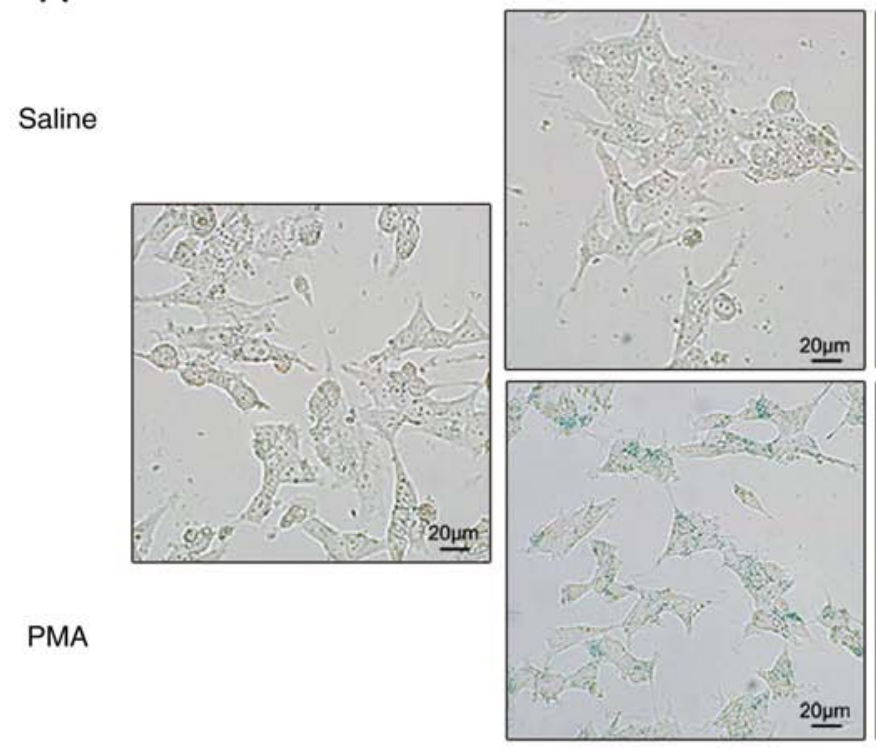

$48 \mathrm{~h}$
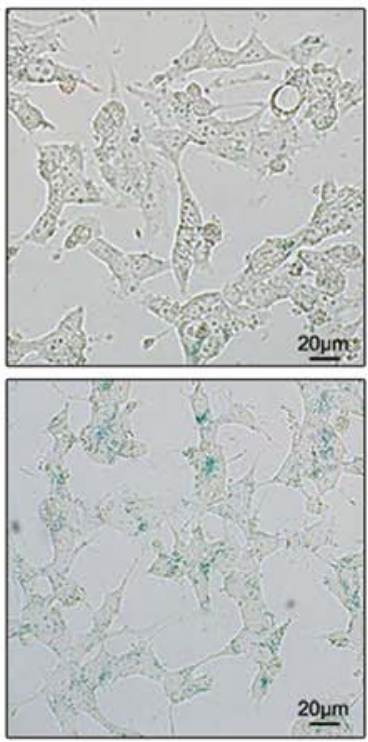

$72 \mathrm{~h}$

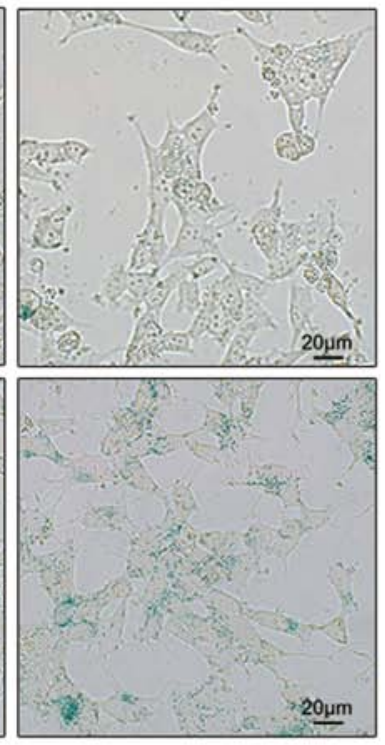

B

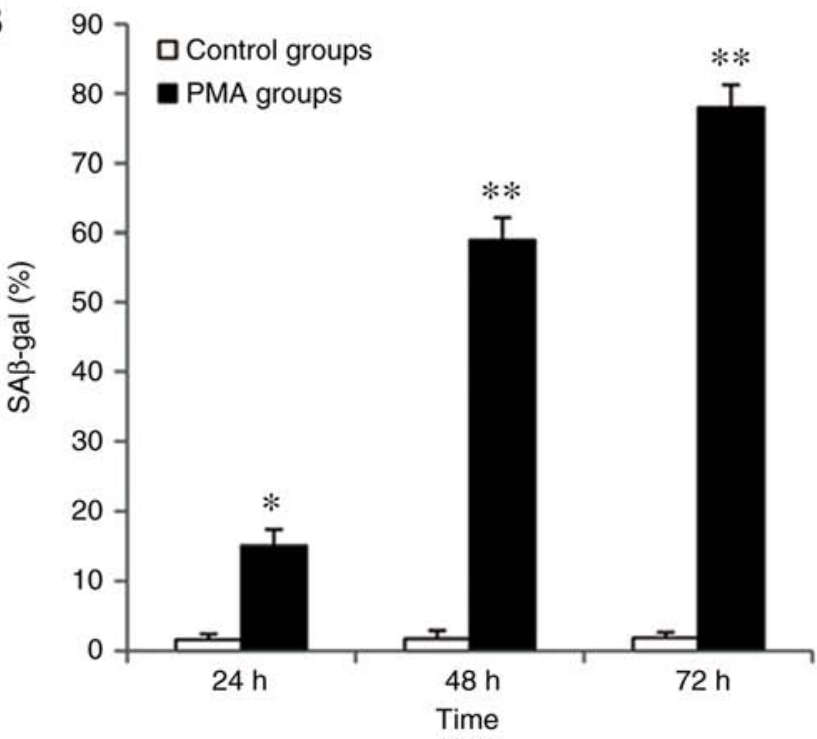

Figure 2. SA- $\beta$-gal staining revealing cellular senescence in response to PMA induction. (A) Microglia treated with PMA for different lengths indicated. SA- $\beta$-Gal signals were observed in cells receiving saline or PMA stimulation for 24,48 or $72 \mathrm{~h}$, respectively, among which, those cells with the PMA simulation for $72 \mathrm{~h}$ showed the strongest signals compared with that in the corresponding saline-treated $72-\mathrm{h}$ group $(\mathrm{n}=10)$. Scale bars $=20 \mu \mathrm{m}$. (B) A higher percentage of SA- $\beta$-Gal positive cells were observed in cells receiving PMA simulation for 24,48 or $72 \mathrm{~h}$, compared with that in their corresponding salinetreated groups, respectively $(\mathrm{n}=10)$. ${ }^{*} \mathrm{P}<0.05$ and ${ }^{* *} \mathrm{P}<0.01$. PMA, phorbol 12 -myristate 13 -acetate; SA- $\beta$-Gal, senescence associated- $\beta$-galactosidase.

darkness, $5 \mu 1$ PI were added 10 min before flow cytometric detection, another $300 \mu \mathrm{l}$ binding buffer was then supplemented till a total volume of $500 \mu 1$ mixture. Triplicates were used for each sample and at least 10,000 cell events were recorded from each sample. Cells were analyzed using an automated flow cytometer (BD Biosciences; FACScan ${ }^{\mathrm{TM}}$ ) to determine the percentages of apoptotic cells with either Annexin $\mathrm{V}^{+} / \mathrm{PI}^{+}$ or Annexin $\mathrm{V}^{-} / \mathrm{PI}^{+}$labeling.

Statistical analysis. Using SPSS 13.0 software (SPSS, Inc.), all data obtained were presented as mean \pm standard error. Statistical differences between groups $(\mathrm{n}=10)$ were determined using one-way or two-way analysis of variance in addition to Bonferroni's test. $\mathrm{P}<0.05$ was considered to indicate a statistically significant difference.

\section{Results}

PMA-induced alterations in microglial cell cycle. A decrease in the cell's proliferative ability is another biomarker of senescence and changes in the cell cycle reflect the proliferative potential of cells. Results from flow cytometry analysis demonstrated that, compared with the control group, the majority of cells from PMA-treated group were found to be arrested at the G0/G1 phase, along with a reduced number of cells at the S phase (Fig. 1A and 1B). Additionally, there was also a rise in the proportion of cells at the G0/G1 phase, when they received a longer duration of PMA stimulation, whereas the percentage of $\mathrm{S}$ phase cells decreased over time (Fig. 1A and 1B). Moreover, statistical significance also indicated an obvious decrease in cell number in PMA-treated 
A
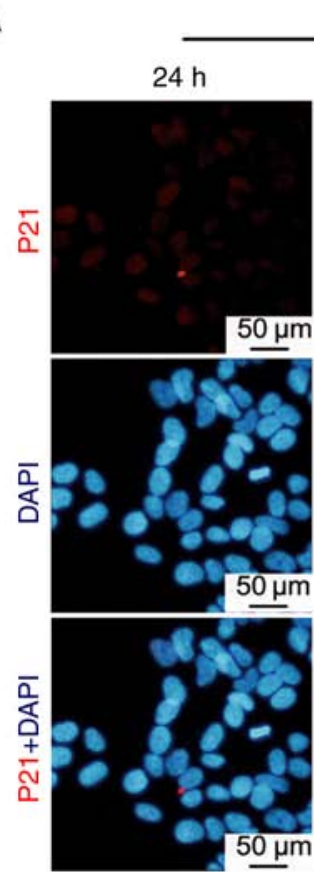

B

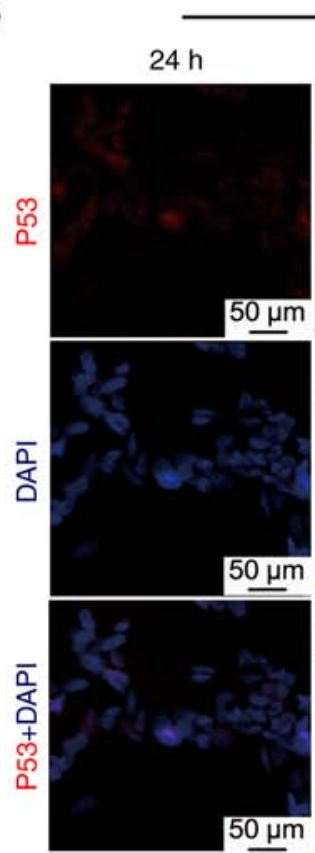

Saline

$48 \mathrm{~h}$
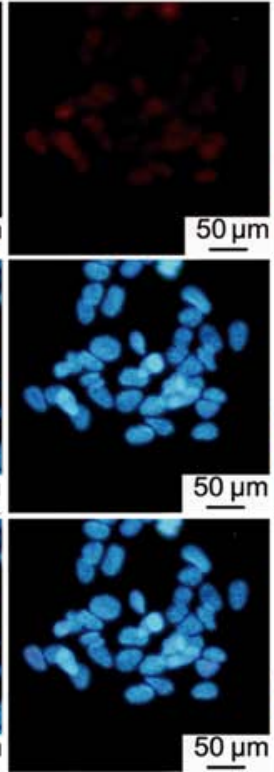

Saline

$48 h$
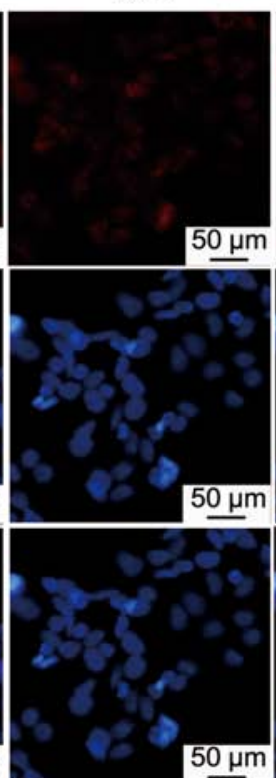

$72 \mathrm{~h}$
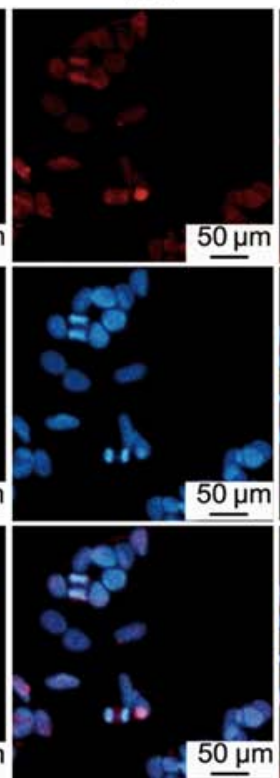

$50 \mu \mathrm{m}$

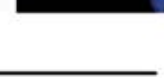

$72 \mathrm{~h}$
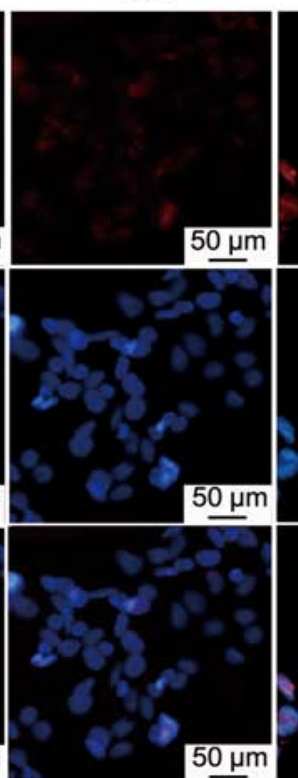

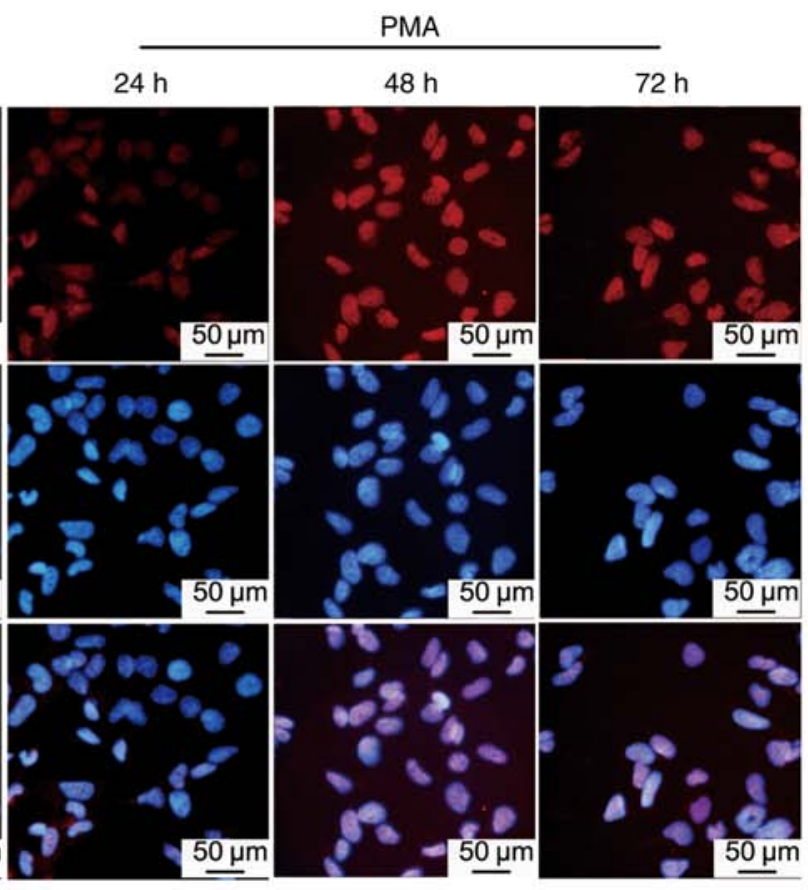

PMA

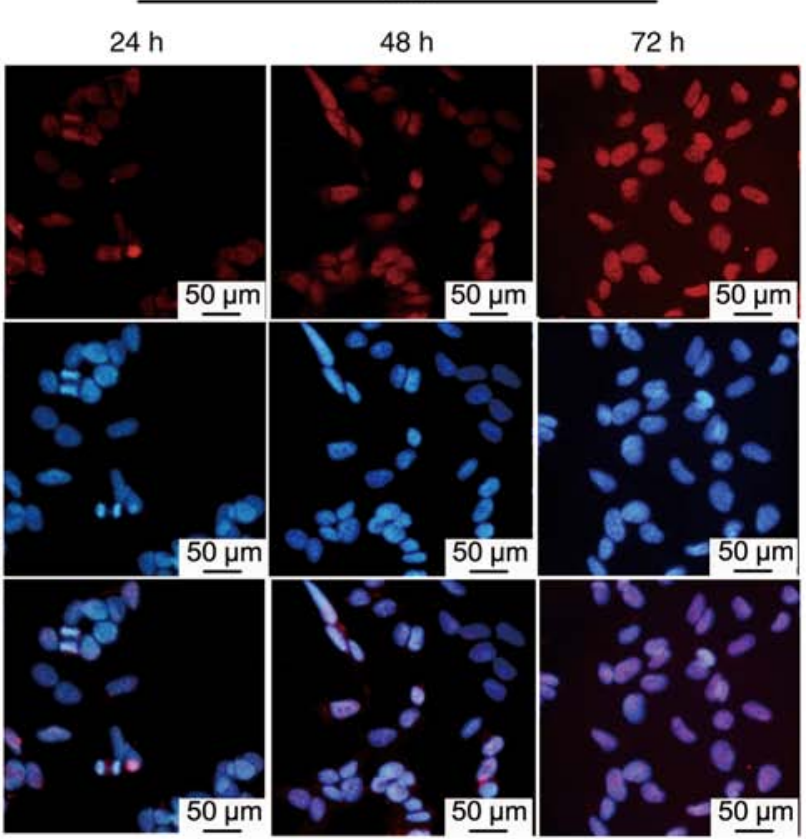

Figure 3. Gene expression and localization of p53 or p21 following PMA induction. Microglia treated with PMA for different time points, i.e. for 24, 48 or $72 \mathrm{~h}$, respectively, as compared with saline-treated 24-h group, followed by evaluation of the expression levels of p53 (A) or p21 (B) protein, as detected via immunofluorescence. Scale bars $=50 \mu \mathrm{m}$. Images are the representative from three independent experiments. PMA, phorbol 12-myristate 13-acetate.

groups with higher concentration over time, compared with the corresponding saline-treated groups $(\mathrm{P}<0.05)$, indicating that PMA treatment induced a gradual stagnation of cell growth and caused a significant decrease in cell proliferation (Fig. 1C). Even though the proliferation of cell number in the control groups increased steadily over time, cells treated with PMA (100 and $200 \mathrm{ng} / \mathrm{ml}$ ) showed a significant inhibition compared with the corresponding control group at 48,72 and $96 \mathrm{~h}$. In particular, $72 \mathrm{~h}$ of administration with $100 \mathrm{ng} / \mathrm{ml}$ PMA was the most effective time point in terms of inhibition of proliferation, given that conditions of $96 \mathrm{~h}$ group showed increased cellular death (Fig. 1C). Therefore, the longest treatment time was set as $72 \mathrm{~h}$ in the following experiments.

Expression of SA- $\beta$-Gal in response to PMA induction. $\beta-\mathrm{Gal}$ is a biomarker that was used to detect cellular senescence. Under conditions of $\mathrm{Ph} 6.0$, a blue signal indicates that the cells have become senescent. Increased blue signals were detected in intracellular particles during cellular senescence (Fig. 2). By comparison, quiescent cells, immortalized cells and tumor cells did not show any positive signal induced by 
A
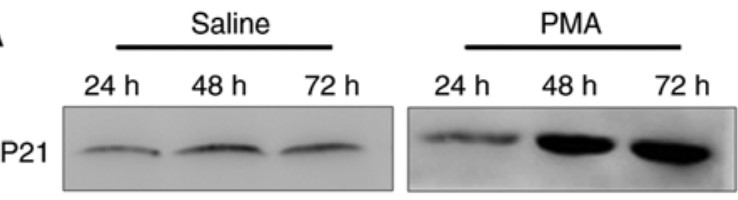

P53
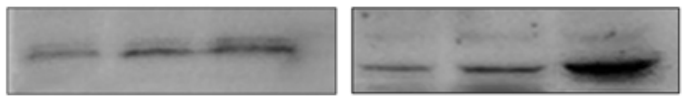

$\beta$-actin
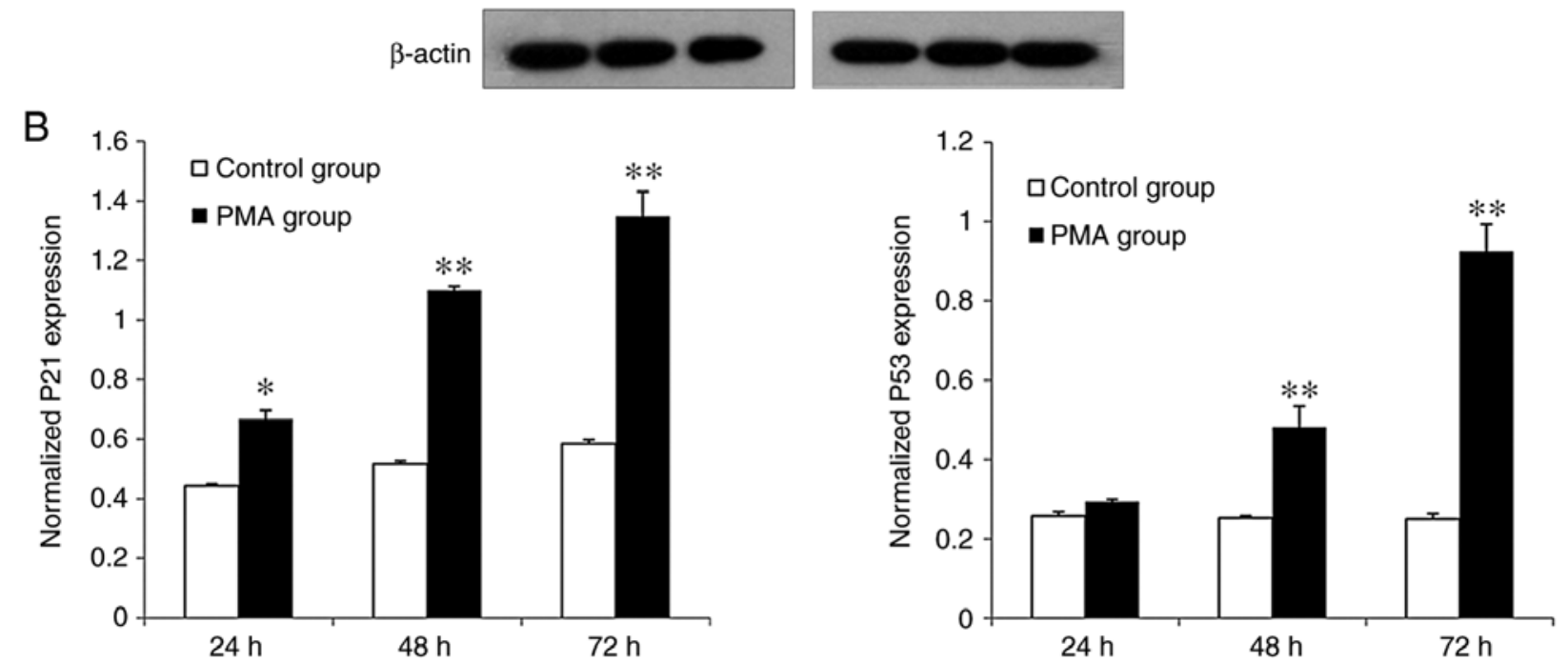

Figure 4. Assessment of p53 or p21 expression following PMA induction. (A) Protein levels of p53 and p21 were evaluated via western blotting. (B) Quantitative assessment for alterations in $\mathrm{p} 53$ or $\mathrm{p} 21$ protein level in response to PMA induction at different time points, i.e. for 24,48 or $72 \mathrm{~h}$, respectively, as compared with control $(\mathrm{n}=10) .{ }^{*} \mathrm{P}<0.05$ and ${ }^{* *} \mathrm{P}<0.01$ vs. the saline-treated 24 -h group. PMA, phorbol 12-myristate 13-acetate.

$\beta$-Gal activity. The present study found that $\beta$-Gal-stained cells were nearly undetectable in each control group, but levels of positively stained cells increased in microglia stimulated with phorbol 12-myristate 13-acetate (PMA) over time (Fig. 2). Additionally, the most robust staining was observed in cells incubated with PMA for $72 \mathrm{~h}$ (Fig. 2).

Expression of $P 53$ and $P 21$ protein in response to PMA induction. Utilizing immunofluorescence and western blotting, protein levels of $\mathrm{p} 53$ and $\mathrm{p} 21$ were examined to detect certain cellular responses to PMA induction. The $\mathrm{p} 21$ and $\mathrm{p} 53$ proteins (marked in red) were tested using immunofluorescence microscopy. very low levels of p21 and p53 were observed in the control group (Fig. 3). However, $24 \mathrm{~h}$ microglial stimulation with PMA increased p21 fluorescence intensity. The intensity of p21 fluorescence gradually increased over time and reached its maximum intensity at $72 \mathrm{~h}$. similar changes were observed in the p53 protein level intensity (Fig. 3).

Through quantitative analyses for western blotting conducted for assessing protein level alterations in p53 and p21 from each group, the results showed that only trace amounts of p53 and p21 protein were detected in cells of the control group (Fig. 4). Compared with the control group, PMA treatment upregulated p53 and p21 protein levels in a time-dependent fashion. When microglia were tested after 24-h PMA treatment, p21 protein expression gradually increased $(\mathrm{P}<0.05)$ and reached its peak amount at $72 \mathrm{~h}(\mathrm{P}<0.01)$. Comparatively, the $\mathrm{p} 53$ protein level was upregulated in a time-dependent manner and moreover, a significantly enhanced expression level of p53 protein was first observed at $48 \mathrm{~h}$ of PMA stimulation and peaked at $72 \mathrm{~h}$ $(\mathrm{P}<0.01)$, respectively (Fig. 4).

Expression of intracellular ROS in response to PMA treatment. In this study, flow cytometry was used to measure fluorescence intensities of intracellular DCF in microglia exposed to PMA and the mean fluorescence intensity values (mean values) were used to evaluate the level of ROS within microglia. Microglia ROS levels in the PMA-treated group displayed an apparent increase, compared with the control group and showed varying degrees of increase after 24, 48 and $72 \mathrm{~h}$ (Fig. 5B). The increase in DCF fluorescence intensity occurred after $24 \mathrm{~h}$ PMA treatment and showed a statistically significant difference regarding intensity values $(\mathrm{P}<0.01)$, compared with the saline-treated 24-h control group. The increase in the DCF fluorescence intensity was time-dependent and peaked after $72 \mathrm{~h}$ of PMA treatment (Fig. 5B). A similar pattern was observed using immunofluorescence microscopy. The control group displayed weak DCF-mediated fluorescence, whereas fluorescence intensity gradually increased after $24 \mathrm{~h}$ in a timedependent manner and the qualitative intensity was highest at 72 h (Fig. 5A).

Detection of IL-1 $\beta$ and TNF- $\alpha$ in microglia treated with PMA for various time points. ELISAs were used to detect the levels of IL-1 $\beta$ as well as TNF- $\alpha$, both of which were secreted by microglia from both the control and PMA-treated groups (Fig. 6). There were also significant differences, regarding 
A
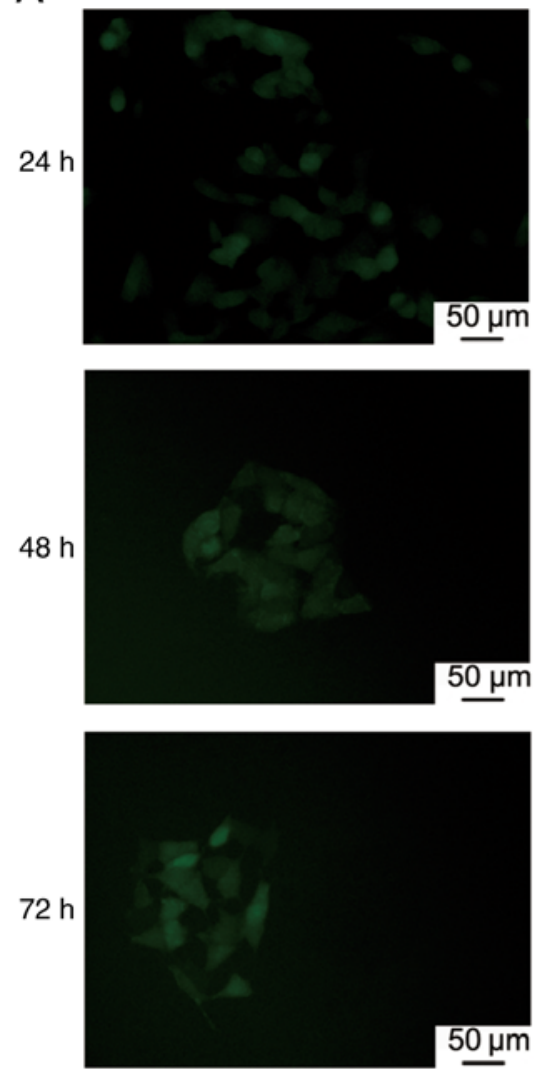

$50 \mu \mathrm{m}$
PMA
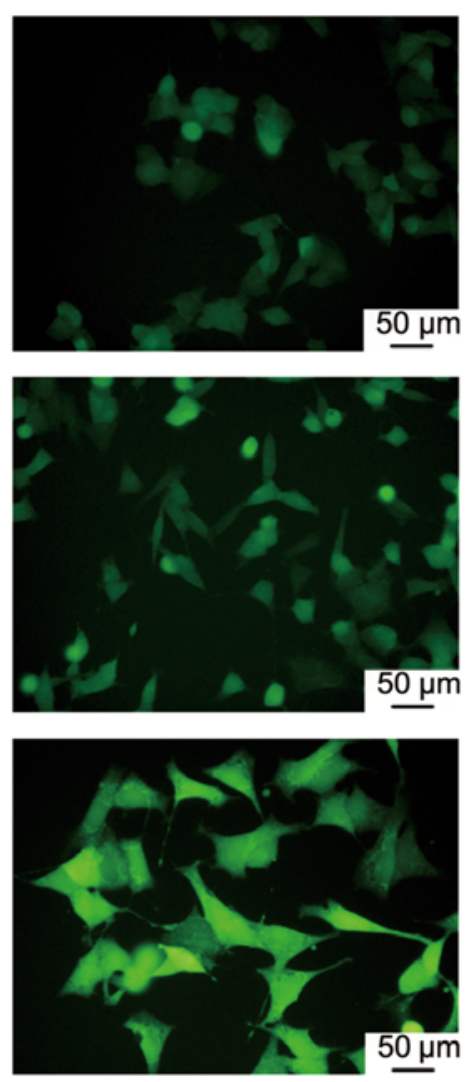

C

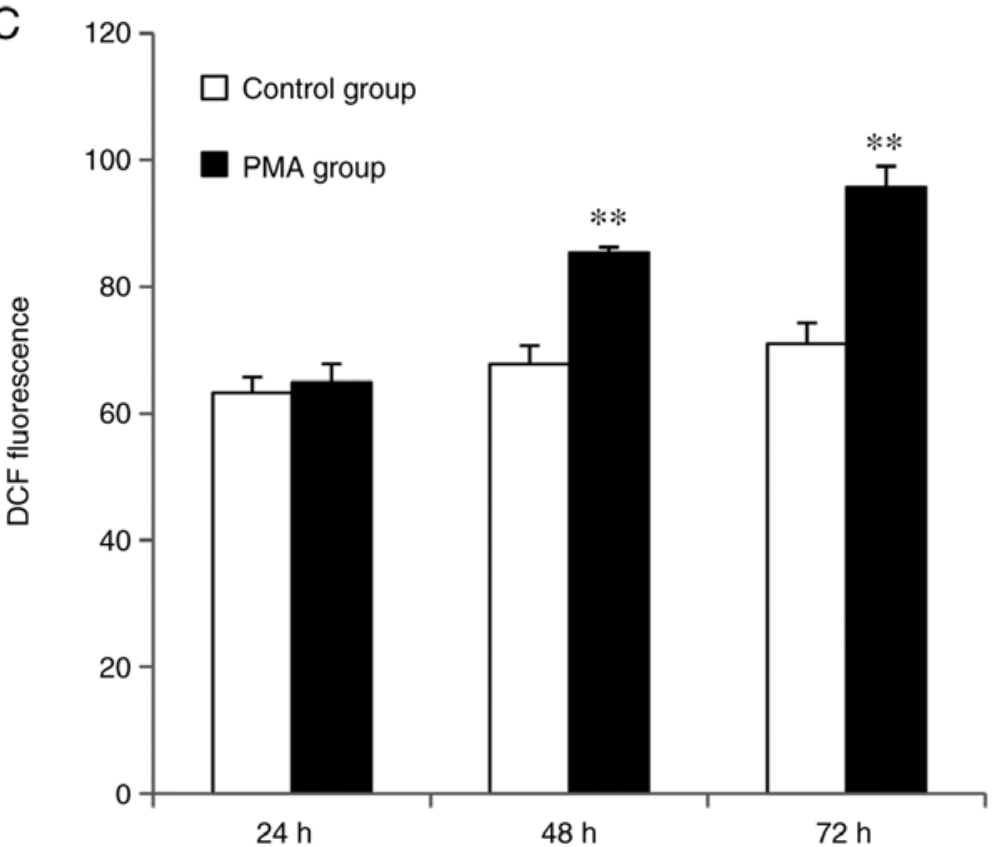

B
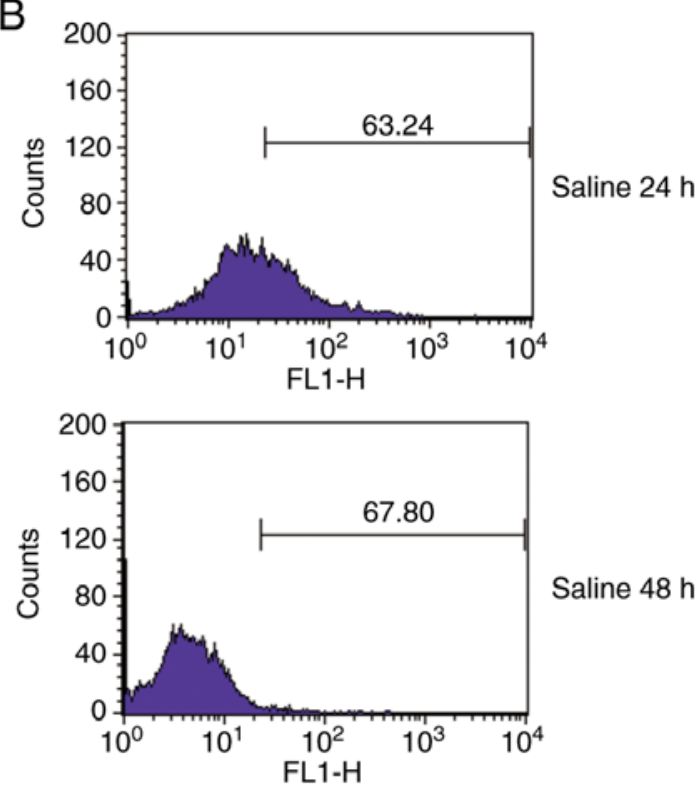

Saline $48 \mathrm{~h}$

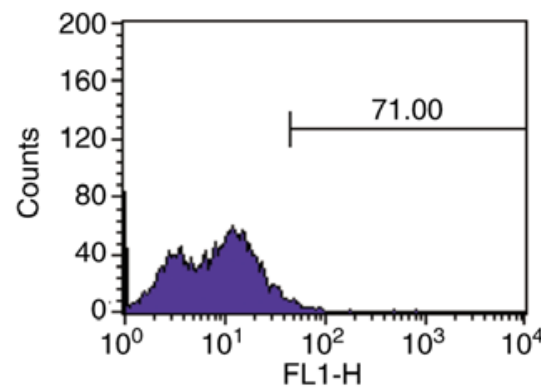

Saline $72 \mathrm{~h}$

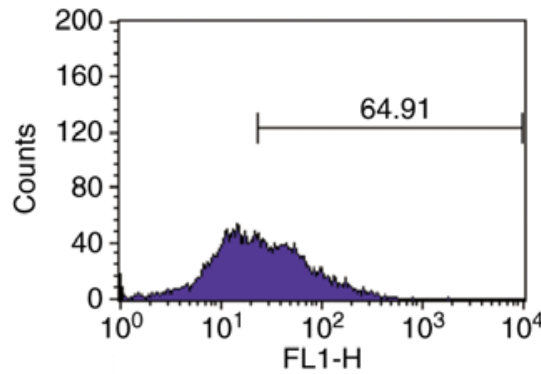

PMA $24 \mathrm{~h}$

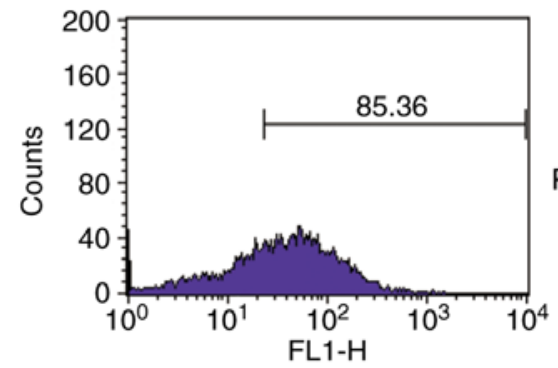

PMA 48 h

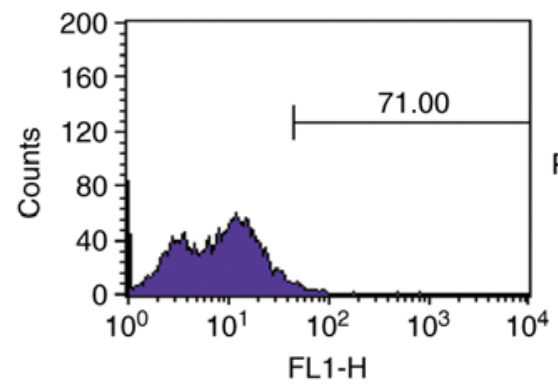

Figure 5. Expression of intracellular ROS in response to PMA treatment. Microglia treated with PMA for different time points. Expression of intracellular ROS were detected by (A) fluorescent confocal microscopy and corresponding quantitative analysis, and they were assessed by (B) flow cytometry and followed by (C) relative quantification as well. Scale bars $=20 \mu \mathrm{m}, \mathrm{n}=10 .{ }^{* *} \mathrm{P}<0.01$ vs. the saline-treated 24-h group. PMA, phorbol 12-myristate 13 -acetate; DCF, dichlorodihydrofluorescein. 

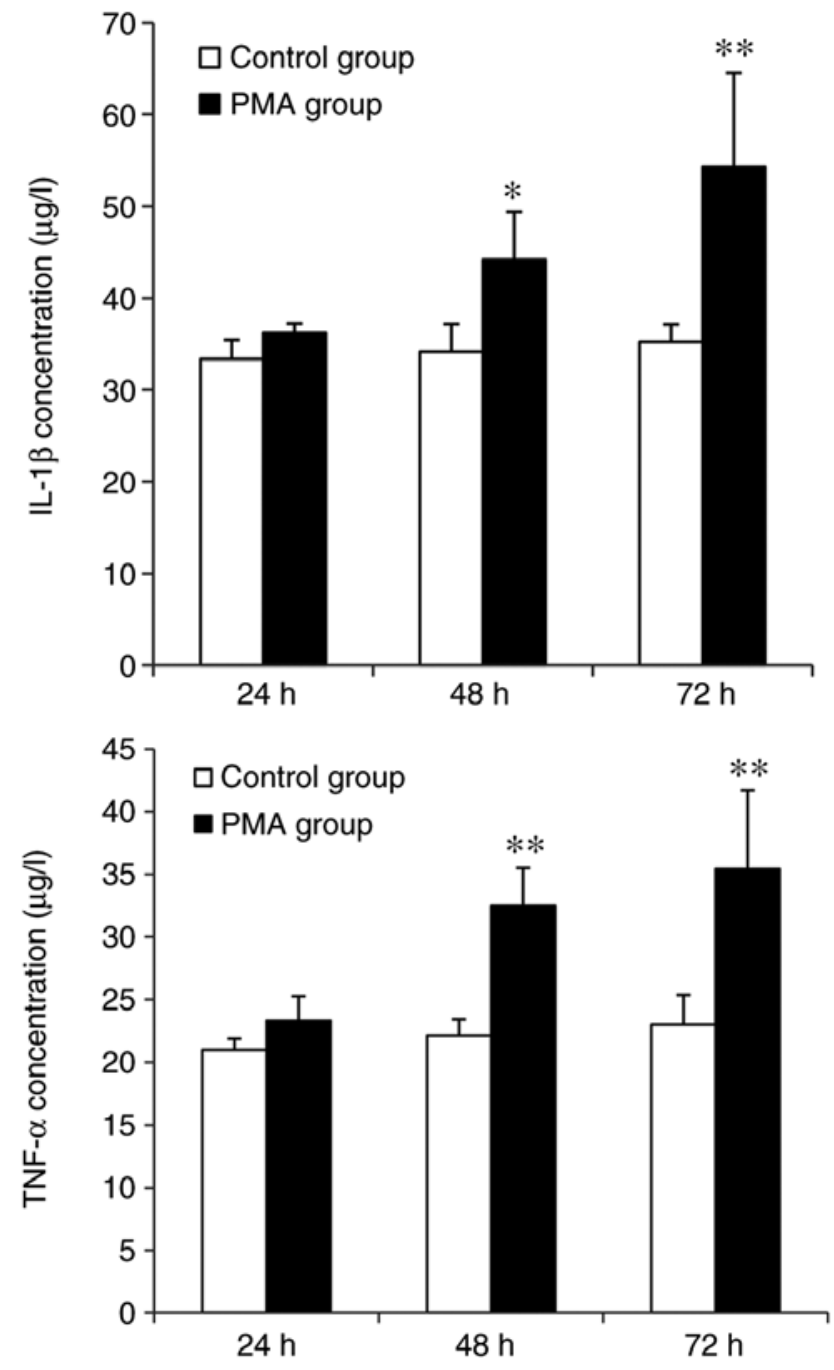

Figure 6. Assessment of expression levels of IL-1 $\beta$ or TNF- $\alpha$ in microglial supernatants following treatment with PMA for different time points. Expression of IL-1 $\beta$ or TNF- $\alpha$ were evaluated by ELISA $(n=10)$. $P<0.05$ and ${ }^{* *} \mathrm{P}<0.01$ vs. the control group. IL, interleukin; TNF, tumor necrosis factor; PMA, phorbol 12-myristate 13-acetate.

levels of TNF- $\alpha$ from the control and PMA-treated groups, both of which were exposed for 48 and $72 \mathrm{~h}$, respectively $(\mathrm{P}<0.05)$. Similarly, significant differences were also noted in the amount of IL-1 $\beta$ secreted by microglia at 48 and $72 \mathrm{~h}$ following PMA stimulation, as compared with the control group $(\mathrm{P}<0.01)$.

Abnormal morphology and apoptosis in PC12 cells following co-culturing with PMA-stimulated microglia. Under brightfield microscopy, PC12 cells in the control group were assessed and found to exhibit spindle- or triangle-shaped morphology and adherent growth (Fig. 7). In contrast, $\mathrm{PC} 12$ cells co-cultured with senescent microglia showed irregular cell morphology. Protruding structures gradually disappeared or were shortened and the cells became smaller and rounded. Flow cytometry analysis of the apoptotic rate demonstrated that, after being co-cultured with senescent microglia, in PC12 cells the apoptosis was apparently enhanced compared to the saline-treated 24-h control group $(\mathrm{P}<0.05$; Fig. 7$)$.

\section{Discussion}

Under physiological conditions, senescence occurs naturally and refers to a relatively stable state of dividing cells that irreversibly lose their proliferative ability and experience morphological changes with increasing age in human patients or animal models (25). Based on whether it is related to telomere shortening, senescence is divided into physiological senescence and pathological senescence. The former is also known as replicative senescence because it is characterized by an increase in cell passages and the gradual loss of telomeric sequences. Pathological senescence is due to the stimulation of non-telomeric signals and is not related to telomere shortening and decreased proliferative capacity. It occurs in response to multiple stimuli under pathological conditions, such as oxidative stress (10) injury (11), radiation (12), tumor protein activation (13), and chemical mutagens (14), and is characterized by the expression of senescence-related proteins, such as p53, p21, and $\beta$-Gal and G0/G1 cell cycle arrest induced by the depletion of ribonucleotide pools without detectable DNA damage under certain conditions (26). This study investigated the possible mechanisms by which carcinogens induce OIS in primary cultures of rat microglia. After stimulating primary microglia with the carcinogen PMA for 24, 48 and $72 \mathrm{~h}$, it was found that microglia displayed a typical pattern of cellular senescence, including cell cycle-arrest phenotypes in the G0/G1 phase, slowed cell proliferation, and reduced numbers of S-phase cells. In addition, time-dependent increases in $\beta$-Gal activity and expression levels of senescence-related proteins p53 and p21 concurrent with PMA-induced inflammation were observed, both of which indicate cellular senescence. During cellular senescence, functional alterations also occurred and hence normal cellular function is compromised. In the present study, it was found that the secretion of inflammatory mediators, including IL-1 $\beta$, TNF- $\alpha$ and ROS, increased with longer PMA induction times and that the viability of PC12 cells decreased after being co-cultured with microglia stimulated by PMA, further confirming that the carcinogen PMA could induce pathological senescence in microglia. Senescent microglia not only show a significant increase in the release of inflammatory mediators (9), but they also have significantly different responses following injury, as compared to that of cultured neurons (27).

OIS is the most common form of pathological senescence. An endogenous protective mechanism used to prepare the body fighting against cancer $(13,17)$. When cells are threatened by malignant transformation, OIS guides cells to terminate their abnormal proliferation and to initiate senescence. Subsequently, OIS-induced senescent cells secrete cytokines, which in turn further promote cellular senescence, thus potentially forming a positive feedback loop (28). Several other studies also pointed out that OIS can also be induced by oncogenes activation (29-32). For instance, moles are considered as cancerous and/or pre-cancerous tissues and are often accompanied by the occurrence of mutations in oncogenes. Oncogenic mutations can induce cell senescence by OIS and thus can prevent benign nevi from developing into a malignant melanoma (33). OIS is, therefore, an endogenous protective mechanism by which the body prevents cancer progression. 

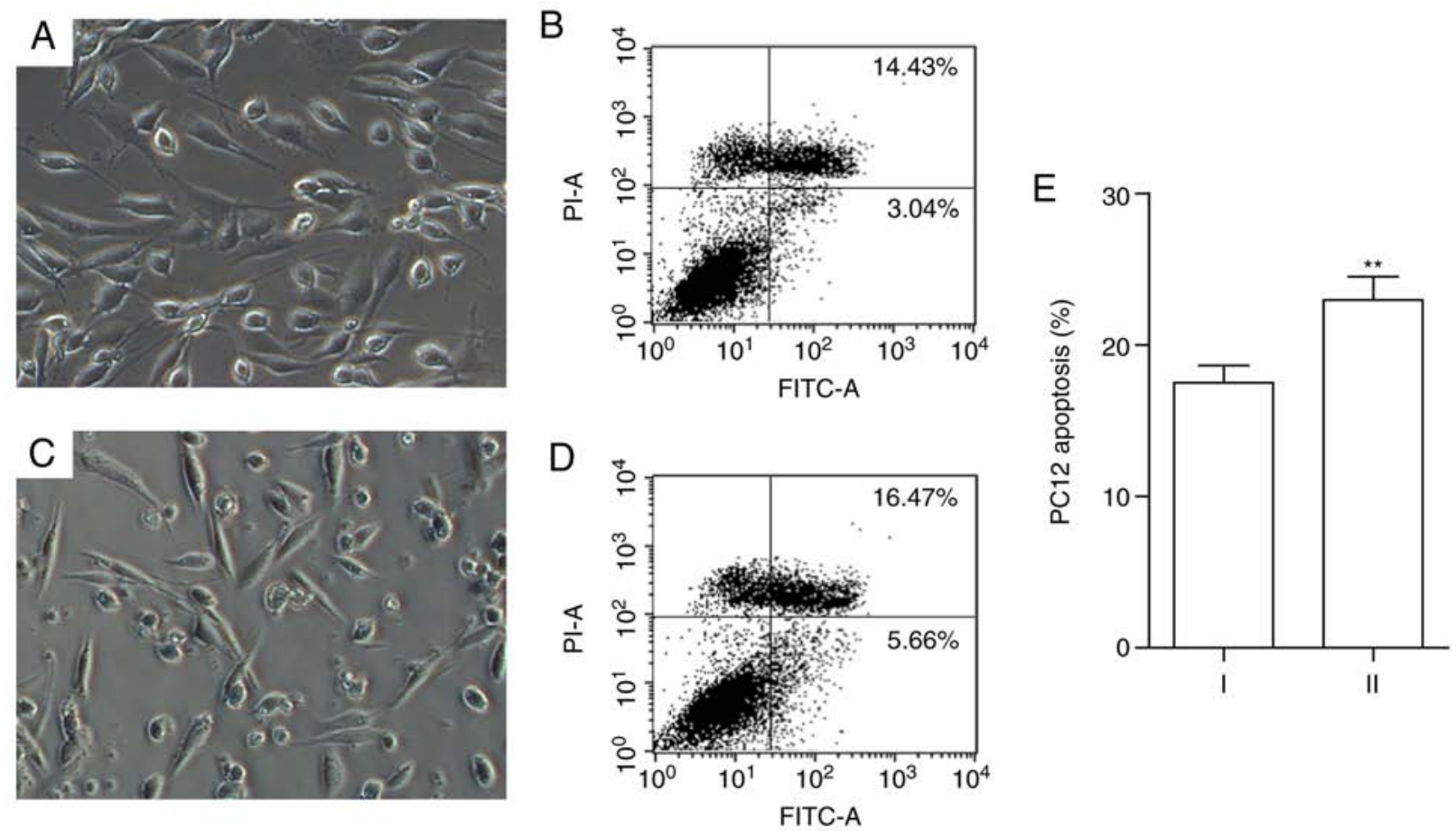

Figure 7. Morphological and flow-cytometric assessment of apoptosis for PC12 cells following PMA stimulation. (A and C) Morphological changes in (B and D) flow-cytometric detection of PC12 apoptosis after being co-cultured with PMA-stimulated microglia ( $\mathrm{n}=10)$. ${ }^{* *} \mathrm{P}<0.01$ vs. the control group. (E) Quantitative analysis of PC12 cells under two conditions, among which, group I (A and B) stands for PC12 culturing alone, while group II (C and D) stands for PC12 co-culturing with PMA-stimulated microglia. PMA, phorbol 12-myristate 13-acetate.

Senescent microglia are a cardinal cell type of the brain's inflammatory microenvironment. During senescence, overactivated microglia will produce and release a large number of cytotoxic factors, such as TNF- $\alpha$, IL- 6 , NO, and ROS, which have toxic effects on neurons and lead to neuronal degeneration and cell death (27,34). IL-1 $\beta$ and TNF- $\alpha$ are two important proinflammatory cytokines released by microglia during the inflammatory process in the CNS. Two previous studies found that inflammatory cytokines are important mediators regulating cellular senescence $(35,36)$. The current study showed that microglia cultured in vitro produced a large amount of IL- $1 \beta$ and TNF- $\alpha$ when stimulated by the carcinogen PMA, suggesting that PMA can induce microglial senescence and promote the release of proinflammatory cytokines, including TNF- $\alpha$ and IL- $1 \beta$, resulting in CNS neuronal damage. Moreover, as shown by the in vitro assays, oxidative stress can also result from PMA administration $(20,37)$. It has been reported previously that ROS are critical factors during the senescence and that subsequent oxidative damage, resulting from ROS accumulation in senescent cells, can cause dysfunctional phenotype(s) (38). Long-term oxidative stress leads to the accumulation of oxidative damage, which elicits cytotoxicity against natural senescence and leads to senescence-related diseases $(39,40)$. Overall, the current study verified these previous findings on the basis of generally consistent results.

The mechanisms underlying senescence are complex and not fully understood. Numerous studies have found a variety of signaling pathways (p16 $6^{\mathrm{INK} 4 \mathrm{a}} / \mathrm{Rb}, \mathrm{p} 53 / \mathrm{p} 21$ and oxidative stress) involved in OIS signal transduction pathways (41-44). As a tumor suppressor, gene p53 is an important regulator of cellular senescence and is triggered by senescence-inducing stimuli. Activated p53 promotes the expression of a variety of downstream target genes, including p21, thereby inhibiting the activity of cyclin A/E and cyclin-dependent kinase 2, preventing $\mathrm{Rb}$ phosphorylation, and leading to the cessation of cell proliferation $(45,46)$. It has been reported that p53 is only transiently increased in senescent cells. In contrast, p21 expression level is increased in senescent cells and even can remain stable under different conditions (47), suggesting that p53 causes cell senescence by activating stable levels of p21 $(48,49)$. The present results also indicate that in PMA-treated rat microglia, p21 protein levels gradually increased during the senescence and were positively correlated with p53 expression.

As a simplified in vitro model, PC12 cells did provide solid as well as reproducible results within a relatively short period of time, however, the authors admit that primary neuron cultures would have been most ideal, which will definitely be employed in future investigations. Moreover, a significant reduction in cell proliferation during PMA-induced microglia senescence was not found. In addition to individual differences in experiment operational performance, culture time may affect cell proliferation. In addition, although common indicators of cellular senescence show sign of aging, they appear to initiate at different time points and increase at different speeds, indicating that they emerge during senescence-associated sequelae. However, the initiating factor remains to be further explored. In short, the current study believes that an in-depth investigation of the mechanism underlying microglia senescence will lay the foundation for future explorations of the role of microglia in PD pathogenesis and lead to the translational application of PD and cancer treatments. 


\section{Acknowledgements}

Not applicable.

\section{Funding}

This study was supported by grants from the China National Nature Science Fund (grant no. 30973153), the Liaoning Doctoral Starting Fund (grant no. 20071042), the Foundation of the Liaoning Educational Committee (grant nos. L202013136 and L2010560), and the Liaoning Foundation for outstanding young scientist, which was awarded to Dr Ren Yan (grant no. LJQ2011081), respectively.

\section{Availability of data and materials}

During the present study, all the data obtained as well as analyzed are available, based on reasonable request to the corresponding author.

\section{Authors' contributions}

YR and XGL designed the majority of the experiments, DC performed investigation data analysis and wrote the manuscript; LW and LSW provided experimental technique assistance; XHL and HMY contributed to interpretation of the data and analyses. All of the authors have read and approved the manuscript.

\section{Ethics approval and consent to participate}

All animal experiments conducted were based on applicable international/national/institutional guidelines for the care and use of laboratory animals, which were approved and supervised by the ethics committee of China Medical University. All data published here are under the consent for publication. Written informed consent was obtained from all individual participants included in the study.

\section{Patient consent for publication}

All data published in the present study are covered under the consent for publication. Written informed consent was obtained from all individual participants included in the study.

\section{Competing interests}

The authors declare they have no competing interests.

\section{References}

1. Lively $\mathrm{S}$ and Schlichter LC: Microglia responses to proinflammatory stimuli (LPS, IFN $\gamma+\mathrm{TNF} \alpha$ ) and reprogramming by resolving cytokines (IL-4, IL-10). Front Cell Neurosci 12: 215, 2018.

2. Wang GQ, Li DD, Huang C, Lu DS, Zhang C, Zhou SY, Liu J and Zhang F: Icariin reduces dopaminergic neuronal loss and microglia-mediated inflammation in vivo and in vitro. Front Mol Neurosci 10: 441, 2018.

3. Heneka MT, Carson MJ, El Khoury J, Landreth GE, Brosseron F, Feinstein DL, Jacobs AH, Wyss-Coray T, Vitorica J, Ransohoff RM, et al: Neuroinflammation in Alzheimer's disease. Lancet Neurol 14: 388-405, 2015
4. Peterson LJ and Flood PM: Oxidative stress and microglial cells in Parkinson's disease. Mediators Inflamm 2012: 401264, 2012.

5. Streit WJ and Xue QS: Human CNS immune senescence and neurodegeneration. Curr Opin Immunol 29: 93-96, 2014.

6. Liu J, Wang MW, Gu P, Ma QY, Wang YY, Geng Y, Yuan ZY, Cui DS, Zhang ZX, Ma L, et al: Microglial activation and age-related dopaminergic neurodegeneration in MPTP-treated SAMP8 mice. Brain Res 1345: 213-220, 2010.

7. Qin L, Wu X, Block ML, Liu Y, Breese GR, Hong JS, Knapp DJ and Crews FT: Systemic LPS cause chronic neuroinflammation and progressive neurodegeneration. Glia 55: 453-462, 2007.

8. Sawada H, Hishida R, Hirata Y, Ono K, Suzuki H, Muramatsu S, Nakano I, Nagatsu T and Sawada M: Activated microglia affect the nigro-striatal dopamine neurons differently in neonatal and aged mice treated with 1-methyl-4-phenyl-1,2,3,6-tetrahydropyridine. J Neurosci Res 85: 1752-1761, 2007.

9. Luo XG, Ding JQ and Chen SD: Microglia in the aging brain: Relevance to neurodegeneration. Mol Neurodegener 5: 12, 2010.

10. $\mathrm{Bu} \mathrm{H}$, Wedel S, Cavinato $\mathrm{M}$ and Jansen-Durr P: MicroRNA regulation of oxidative stress-induced cellular senescence. Oxid Med Cell Longev 2017: 2398696, 2017.

11. Borlon C, Chretien A, Debacq-Chainiaux F and Toussaint O: Transient increased extracellular release of $\mathrm{H} 2 \mathrm{O} 2$ during establishment of UVB-induced premature senescence. Ann N Y Acad Sci 1119: 72-77, 2007.

12. Debacq-Chainiaux F, Leduc C, Verbeke A and Toussaint O: UV, stress and aging. Dermatoendocrinol 4: 236-240, 2012.

13. Mooi WJ and Peeper DS: Oncogene-induced cell senescencehalting on the road to cancer. N Engl J Med 355: 1037-1046, 2006.

14. Kovatcheva M, Liu DD, Dickson MA, Klein ME, O'Connor R, Wilder FO, Socci ND, Tap WD, Schwartz GK, Singer S, et al: MDM2 turnover and expression of ATRX determine the choice between quiescence and senescence in response to CDK4 inhibition. Oncotarget 6: 8226-8243, 2015.

15. Itahana K, Campisi J and Dimri GP: Methods to detect biomarkers of cellular senescence: The senescence-associated beta-galactosidase assay. Methods Mol Biol 371: 21-31, 2007.

16. Macip S, Igarashi M, Fang L, Chen A, Pan ZQ, Lee SW and Aaronson SA: Inhibition of p21-mediated ROS accumulation can rescue p21-induced senescence. EMBO J 21: 2180-2188, 2002.

17. Serrano M: Cancer regression by senescence. N Engl J Med 356: 1996-1997, 2007.

18. Serrano M, Lin AW, McCurrach ME, Beach D and Lowe SW: Oncogenic ras provokes premature cell senescence associated with accumulation of p53 and p16INK4a. Cell 88: 593-602, 1997.

19. Li YH, Bi HC, Huang L, Jin J, Zhong GP, Zhou XN and Huang M: Phorbol 12-myristate 13-acetate inhibits P-glycoproteinmediated efflux of digoxin in MDCKII-MDR 1 and Caco-2 cell monolayer models. Acta Pharmacol Sin 35: 283-291, 2014.

20. Liu L, Luo XG, Yu HM, Feng Y, Ren Y, Yin YF, Shang H and He ZY: Repeated intra-nigrostriatal injection of phorbol myristate acetate induces microglial senescence in adult rats. Mol Med Rep 12: 7271-7278, 2015.

21. Mowla S, Pinnock R, Leaner VD, Goding CR and Prince S: PMA-induced up-regulation of TBX3 is mediated by AP-1 and contributes to breast cancer cell migration. Biochem $\mathrm{J} 433$ : 145-153, 2011.

22. Aschner M and Kimelberg HK: The use of astrocytes in culture as model systems for evaluating neurotoxic-induced-injury. Neurotoxicology 12: 505-517, 1991.

23. Moreno JA, Sullivan KA, Carbone DL, Hanneman WH and Tjalkens RB: Manganese potentiates nuclear factor-kappaBdependent expression of nitric oxide synthase 2 in astrocytes by activating soluble guanylate cyclase and extracellular responsive kinase signaling pathways. J Neurosci Res 86: 2028-2038, 2008.

24. Carbone DL, Popichak KA, Moreno JA, Safe S and Tjalkens RB: Suppression of 1-methyl-4-phenyl-1,2,3,6-tetrahydropyridineinduced nitric-oxide synthase 2 expression in astrocytes by a novel diindolylmethane analog protects striatal neurons against apoptosis. Mol Pharmacol 75: 35-43, 2009.

25. Cichowski K and Hahn WC: Unexpected pieces to the senescence puzzle. Cell 133: 958-961, 2008.

26. Kim KH and Sederstrom JM: Assaying cell cycle status using flow cytometry. Curr Protoc Mol Biol 111: 28.6.1-28.6.11, 2015.

27. Polazzi E and Contestabile A: Reciprocal interactions between microglia and neurons: From survival to neuropathology. Rev Neurosci 13: 221-242, 2002.

28. Lehmann AR and Carr AM: The ataxia-telangiectasia gene: A link between checkpoint controls, neurodegeneration and cancer. Trends Genet 11: 375-377, 1995. 
29. Chinta SJ, Lieu CA, Demaria M, Laberge RM, Campisi J and Andersen JK: Environmental stress, ageing and glial cell senescence: A novel mechanistic link to Parkinson's disease? J Intern Med 273: 429-436, 2013.

30. Collado M, Gil J, Efeyan A, Guerra C, Schuhmacher AJ, Barradas M, Benguria A, Zaballos A, Flores JM, Barbacid M, et al: Tumour biology: Senescence in premalignant tumours. Nature 436: 642, 2005.

31. Dhomen N, Reis-Filho JS, da Rocha Dias S, Hayward R Savage K, Delmas V, Larue L, Pritchard C and Marais R: Oncogenic Braf induces melanocyte senescence and melanoma in mice. Cancer Cell 15: 294-303, 2009.

32. Sarkisian CJ, Keister BA, Stairs DB, Boxer RB, Moody SE and Chodosh LA: Dose-dependent oncogene-induced senescence in vivo and its evasion during mammary tumorigenesis. Nat Cell Biol 9: 493-505, 2007

33. Michaloglou C, Vredeveld LC, Soengas MS, Denoyelle C, Kuilman T, van der Horst CM, Majoor DM, Shay JW, Mooi WJ and Peeper DS: BRAFE600-associated senescence-like cell cycle arrest of human naevi. Nature 436: 720-724, 2005.

34. More SV, Kumar H, Kim IS, Song SY and Choi DK: Cellular and molecular mediators of neuroinflammation in the pathogenesis of Parkinson's disease. Mediators Inflamm 2013: 952375, 2013.

35. Acosta JC, O'Loghlen A, Banito A, Guijarro MV, Augert A Raguz S, Fumagalli M, Da Costa M, Brown C, Popov N, et al: Chemokine signaling via the CXCR2 receptor reinforces senescence. Cell 133: 1006-1018, 2008.

36. Kuilman T, Michaloglou C, Vredeveld LC, Douma S, van Doorn R, Desmet CJ, Aarden LA, Mooi WJ and Peeper DS: Oncogene-induced senescence relayed by an interleukin-dependent inflammatory network. Cell 133: 1019-1031, 2008.

37. Kumar A, Chen SH, Kadiiska MB, Hong JS, Zielonka J, Kalyanaraman B and Mason RP: Inducible nitric oxide synthase is key to peroxynitrite-mediated, LPS-induced protein radical formation in murine microglial BV2 cells. Free Radic Biol Med 73: 51-59, 2014.

38. Irani K: Oxidant signaling in vascular cell growth, death, and survival: A review of the roles of reactive oxygen species in smooth muscle and endothelial cell mitogenic and apoptotic signaling. Circ Res 87: 179-183, 2000.
39. Harman D: The free radical theory of aging. Antioxid Redox Signal 5: 557-561, 2003.

40. Park ES, Kim SR and Jin BK: Transient receptor potential vanilloid subtype 1 contributes to mesencephalic dopaminergic neuronal survival by inhibiting microglia-originated oxidative stress. Brain Res Bull 89: 92-96, 2012.

41. Chandeck C and Mooi WJ: Oncogene-induced cellular senescence. Adv Anat Pathol 17: 42-48, 2010.

42. Coppe JP, Rodier F, Patil CK, Freund A, Desprez PY and Campisi J: Tumor suppressor and aging biomarker p16(INK4a) induces cellular senescence without the associated inflammatory secretory phenotype. J Biol Chem 286: 36396-36403, 2011.

43. Moiseeva O, Bourdeau V, Roux A, Deschenes-Simard X and Ferbeyre G: Mitochondrial dysfunction contributes to oncogeneinduced senescence. Mol Cell Biol 29: 4495-4507, 2009.

44. Reddy JP and Li Y: Oncogene-induced senescence and its role in tumor suppression. J Mammary Gland Biol Neoplasia 16: 247-256, 2011.

45. Fitzgerald AL, Osman AA, Xie TX, Patel A, Skinner H, Sandulache V and Myers JN: Reactive oxygen species and p21Waf1/Cip1 are both essential for p53-mediated senescence of head and neck cancer cells. Cell Death Dis 6: e1678, 2015.

46. Gatza C, Moore L, Dumble M and Donehower LA: Tumor suppressor dosage regulates stem cell dynamics during aging. Cell Cycle 6: 52-55, 2007.

47. John R, Chand V, Chakraborty S, Jaiswal N and Nag A: DNA damage induced activation of Cygb stabilizes p53 and mediates G1 arrest. DNA Repair (Amst) 24: 107-112, 2014.

48. Chandler H and Peters G: Stressing the cell cycle in senescence and aging. Curr Opin Cell Biol 25: 765-771, 2013.

49. Kim YY, Jee HJ, Um JH, Kim YM, Bae SS and Yun J: Cooperation between p21 and Akt is required for p53-dependent cellular senescence. Aging Cell 16: 1094-1103, 2017. 